\title{
Investigation of agility performance on 10-12 years soccer players
}

\author{
Özcan Saygın ${ }^{1}$ \\ Kemal Göral ${ }^{2}$ \\ Halil İbrahim Ceylan ${ }^{3}$ \\ Sevcan Karacabey ${ }^{4}$
}

\begin{abstract}
This research was carried out for investigation of 10-12 age soccer players' agility performance according to age. 53 male soccer players attended in this research voluntarily. Illinois agility test was used in the assessment of agility performance. Collected data was recorded in SPSS program. One Way Variance Analyze (ANOVA) was used for determination of differences in different group soccer players. When difference was discerned among groups, Tukey HSD analyses were used for detecting which groups cause this difference. Significance level was accepted as $\mathrm{p}<0.05$. According to research results, significant differences were determined among 10, 11 and 12 age group soccer players' agility performances $(\mathrm{p}<0.01)$. The sources of differences were those, 12 age group soccer players according to 10 and 11 age group showed better performances. Consequently, It can be said that agility feature consisting suddenly stop, change direction and acceleration actions are effected by age in these groups.
\end{abstract}

Keywords: Age; Agility; Child; Soccer.

\section{Introduction}

Soccer is one of the most beloved and popular sports branches both in the World and Turkey. Key to success in soccer depends first of all on finding appropriate players and enhancing these player's performances. Movements related to anaerobic energy such as short-range sprints, abrupt halts, abrupt deflections which are short dated and high volume often come into being in soccer (Gunay and Yuce, 2008).

Agility, as a reaction to stimulus from environment, it is defined as a movement consisting abrupt and fast deflection. For example agility can be identified as an unplanned movement such as abrupt speed-up or slow-down in order to get rid of rival player's movements whom we met on a

\footnotetext{
${ }^{1}$ Assoc. Prof. Dr., Mugla Sitki Kocman University, Faculty of Sport Sciences, ozsaygin@,hotmail.com 2Ph.D., Mugla Sitki Kocman University, Faculty of Sport Sciences, kemalgoral32@,hotmail.com ${ }^{3}$ Research Assistant, Mugla Sitki Kocman University, Faculty of Sport Sciences, halil.ibrahimceylan60@gmail.com ${ }^{4}$ Gaziantep University, Institute of Health Sciences, kkaracabey@hotmail.com
} 
Sayg1n, Ö., Göral, K., Ceylan, H. İ., \& Karacabey, S. (2015). Investigation of agility performance on 10-12 years soccer players. International Journal of Human Sciences, 12(2), 1912-1917. doi:10.14687/ijhs.v12i2.3521

straight line (Sheppard and Young, 2006). According to identification, agility is ability of changing body direction effectively and productively (Verschuren, Bloemen, Kruitwagen and Takken, 2010).

Measurement of agility performance is important in terms with sportsmen's development planning. In order to determine agility performance, several of field tests which can easily be performed by trainers and players are developed. Common characteristic of these tests are their applicability in field and their measurability with simple measuring sets. Illinois Agility Test, Agility Test, 505 Agility Test, Pro-Agility Test are some of tests which are used in sports commonly (Karacabey, 2013; Young and Farrow, 2006; Sheppard and Young, 2006). Intended level development of agility will be a powerful base for the control of motor skills and neuromotor system. It is known that abrupt deflections are the main reasons of mutilation. As a result of improving agility in desired level individual movement mechanics also develop and mutilation risk lessens. Arising of fast deflection ability will be helpful both for attack and defense. Generally it will be helpful for arising performance (Little and Williams, 2005). In the light of this data, this study was carried out for investigation of 10-12 age soccer players' agility performances according to age.

\section{Materials and Methods}

Fifty-three (average age: 11.09 \pm 0.81$)^{\text {soccer player }\left(10 \text { age }_{(\mathrm{n}=15)}, 11 \text { age }\right.}(\mathrm{n}=18), 12$ age $\left.{ }_{(\mathrm{n}=20)}\right)$ attended in this study voluntarily. Illinois agility test was used to determine the agility characteristics of players. Measurements were carried out in competition periods, resting days and after warm up sessions. Body-weight was measured by 0.1 susceptible electronic scales. Height was measured by $0.01 \mathrm{~cm}$ susceptible digital measure. "Body-Mass Index (BMI) = Body Weight/ Height $(m)^{2}$ formula was used in the calculation of body-mass index (Tamer, 2000; Zorba and Saygin, 2009).

Illinois Agility Test: Test racetrack made up of width $5 \mathrm{~m}$, height $10 \mathrm{~m}$ and middle $3,3 \mathrm{~m}$ spaced level line three cones is set in sports hall. Test consists of $180^{\circ}$ rotations every $10 \mathrm{~m}$. Of these $40 \mathrm{~m}$ is flat; $20 \mathrm{~m}$ is slalom running among cones. When racetrack was set, double door photocell electronic chronometer were placed at start and finish points. Players checked out from start point of racetrack facedown and hands on shoulder length and in contact with place. And completion duration was recorded in terms of seconds. Test was repeated two times and best score was evaluated. (Amiri-Khorasani, Sahebozamani, Tabrizi and Yusof, 2010; Karacabey, 2013; Hazir, Mahir and Acikada, 2010). 


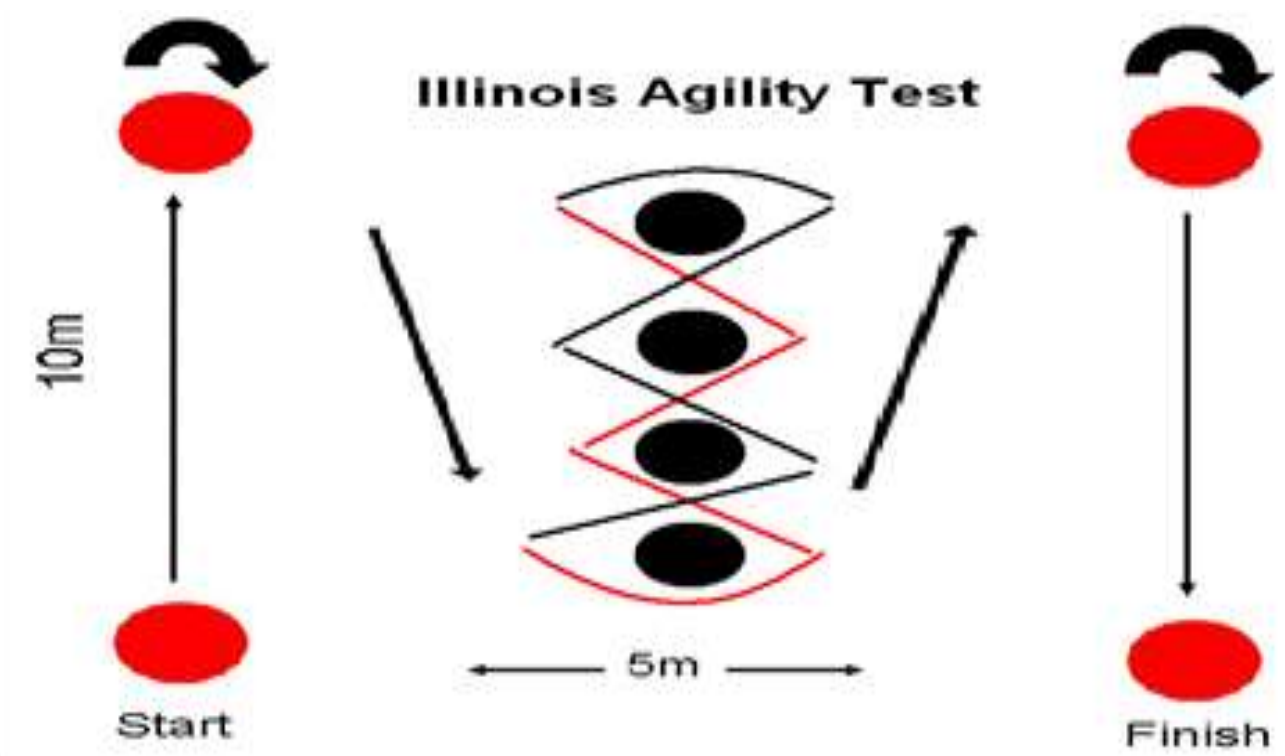

\section{Statistical Analysis:}

Collected data was recorded in SPSS program. One Way Variance Analyze (ANOVA) was used for determination of differences in different group soccer players. When difference was discerned among groups, Tukey HSD analyses were used for detecting which groups cause this difference. Significance level was accepted as $\mathrm{p}<0.05$.

\section{Results}

Table 1: Illinois agility test, body mass index, height and weight values of 10-12 age soccer players

\begin{tabular}{lcccc}
\hline Variables & Age & Mean \pm SD & F & P \\
\hline \multirow{2}{*}{ Height $(\mathrm{cm})$} & 10 & $149.60 \pm 2.16$ & & $0.000^{* *}$ \\
& 11 & $152.67 \pm 1.81$ & 25.167 & \\
Weight $(\mathrm{kg})$ & 12 & $154.30 \pm 1.89$ & & $0.000^{* *}$ \\
& 10 & $40.27 \pm 1.28$ & 59.226 & $0.000^{* *}$ \\
Body Mass Index $\left(\mathrm{kg} / \mathrm{m}^{2}\right)$ & 11 & $42.44 \pm 1.54$ & & \\
& 12 & $46.80 \pm 2.33$ & 17.337 & $0.000^{* *}$ \\
\hline \multirow{2}{*}{ Illinois Agility Test $(\mathrm{sec})$} & 10 & $18.01 \pm 0.84$ & & \\
\end{tabular}

${ }^{* *} \mathrm{p}<0.01$

According to the findings of this study, significant differences were found in height, weight, body mass index and agility performance values among 10,11 and 12 age group soccer player $(p<0.01)$ 
Table 2: The results of Tukey HSD for 10-12 age soccer players

\begin{tabular}{|c|c|c|c|}
\hline Variables & Age (I) & Age $(\mathrm{J})$ & Difference (I-J) \\
\hline \multirow{6}{*}{ Height $(\mathrm{cm})$} & \multirow{2}{*}{10} & 11 & $-3.066^{*}$ \\
\hline & & 12 & $-4.700^{*}$ \\
\hline & \multirow{2}{*}{11} & 10 & $3.066^{*}$ \\
\hline & & 12 & $-1.633^{*}$ \\
\hline & \multirow{2}{*}{12} & 10 & $4.700^{*}$ \\
\hline & & 11 & $1.633^{*}$ \\
\hline \multirow{6}{*}{ Weight (kg) } & \multirow{2}{*}{10} & 11 & $-2.177^{*}$ \\
\hline & & 12 & $-6.533^{*}$ \\
\hline & \multirow{2}{*}{11} & 10 & $2.177^{*}$ \\
\hline & & 12 & $-4.355^{*}$ \\
\hline & \multirow{2}{*}{12} & 10 & $6.533^{*}$ \\
\hline & & 11 & $4.355^{*}$ \\
\hline \multirow{6}{*}{ Body Mass Index $\left(\mathrm{kg} / \mathrm{m}^{2}\right)$} & \multirow{2}{*}{10} & 11 & -0.217 \\
\hline & & 12 & $-1.656^{*}$ \\
\hline & \multirow{2}{*}{11} & 10 & 0.217 \\
\hline & & 12 & $-1.438^{*}$ \\
\hline & \multirow{2}{*}{12} & 10 & $1.656^{*}$ \\
\hline & & 11 & $1.438^{*}$ \\
\hline \multirow{6}{*}{ Illinois Agility Test (sec) } & \multirow{2}{*}{10} & 11 & 0.261 \\
\hline & & 12 & $1.945^{*}$ \\
\hline & \multirow{2}{*}{11} & 10 & -0.261 \\
\hline & & 12 & $1.683^{*}$ \\
\hline & \multirow{2}{*}{12} & 10 & $-1.945^{*}$ \\
\hline & & 11 & $-1.683^{*}$ \\
\hline
\end{tabular}

${ }_{\mathrm{p}}<0.05$

\section{Discussion and Conclusion}

Agility is identified as body's fast turnaround ability composing as a result of combination of agility, power, speed balance and coordination characteristics (Bidaurrazaga-Letona et al., 2015). According to Homoud (2015), agility is significant component of activities requiring high speed (acceleration, maximal speed) especially of field and team sports and it is one of the main technical factors for sportive success in soccer (Alanazi and Aouadi, 2015; Homoud, 2015).

In this study, agility performance was investigated according to age in 10-12 age soccer players. Looking at the results of this study, significant differences were found in height, weight, body mass index and Illinois agility test performance among 10,11 and 12 age group soccer player $(\mathrm{p}<0.01)$. While the height of soccer players aged 10,11, 12 years were found $149.60 \pm 2.16 \mathrm{~cm}$, $152.67 \pm 1.81 \mathrm{~cm}$ and $154.30 \pm 1.89 \mathrm{~cm}$, respectively, the weight of soccer players aged 10,11,12 years were found $40.27 \pm 1.28 \mathrm{~kg}, 42.44 \pm 1.54 \mathrm{~kg}$ and $46.80 \pm 2.33 \mathrm{~kg}$, respectively. Body mass index of players were found to be $18.01 \pm 0.84 \mathrm{~kg} / \mathrm{m}^{2}, 18.22 \pm 0.88 \mathrm{~kg} / \mathrm{m}^{2}$ and $19.66 \pm 1.02 \mathrm{~kg} / \mathrm{m}^{2}$ aged 10, 11, 12 years old, respectively. Illinois Agility Test values of players were found to be $22.80 \pm 0.71 \mathrm{sec}$., $22.54 \pm 0.75 \mathrm{sec}$, and $20.85 \pm 0.94 \mathrm{sec}$., respectively. Reason of this difference was that 12 age group soccer players performed better that 11 and 10 age group. 
Sayg1n, Ö., Göral, K., Ceylan, H. İ., \& Karacabey, S. (2015). Investigation of agility performance on 10-12 years soccer players. International Journal of Human Sciences, 12(2), 1912-1917. doi:10.14687/ijhs.v12i2.3521

Bidaurrazaga-Letona et al., (2015) determined that 13 age and average age 12.0 \pm 0.8 year soccer players showed better agility performances than average age $10.4 \pm 0.3$ year and 11 aged soccer players. And it was also seen that both age group agility performance's optimization rates are close to eachothers. In literature, studies investigating agility time according to age and saying that the older was the age the better was the agility performance and age was an significant factor in determining the agility performance are available (Bidaurrazaga-Letona et al., 2015; Dellal and Wong, 2013; Zemkova and Hamar, 2014; Cetin, 2013).

The study was conducted was by Zemkova and Hamar (2014) examined agility performances on 553 children and adolescents in 7-18 ages. 27.1\% optimization was seen in 7-10 age agility times. $26.5 \%$ optimization was seen 10-14 age agility times. Among 14-18 ages namely puberty period $(16.5 \%)$ little optimization was seen in agility times. Consequently it was reported that the older was the age the more optimization was in agility timing until precocious puberty. Cetin (2013) investigated if there was a difference in agility performances according to age in 7-12 age children. 83 male attended in this study. Males 7-8 age; 9-10 age and 11-12 age were divided into three groups. Illlionis agility test was used to determine the agility performances. In conclusion, it was seen that agility performance rises together with age. In males agility performance values were in turn $24.5 \pm 2.5,22.6 \pm 1.6,21.3 \pm 1.9$ sec. $11-12$ age group males showed $5.7 \%$ better agility performance than 9-10 age group males. Also they showed $13.1 \%$ better agility performances than 7-8 age group performances. $9-10$ age group males showed 7.7\% better agility performance than 7-8 age groups. Kizilet, Atilan and Erdemir (2010) found that average age $13.00 \pm 0.95$ years, training ages $3 \pm 1$ years and 12 basketball player's Illionis agility test performances were $20.13 \pm 1.39$ seconds with balls and without balls they were $18.65 \pm 1.03$ seconds.

Rowland (2005) emphasizes that characteristic such as motor skill, strength, sprint and speed which were ongoing process of development continued throughout childhood. The study was managed by Pettersen and Mathisen (2012) on 11-12 year old boys studied the development of agility, acceleration and speed performance. According to results of the study, improvement of the acceleration, speed and agility performance of this age group were $2.1 \%, 1.8 \%, 3.5 \%$, respectively. The biggest improvement was found in agility performance as 3.5\%.

As regards to research results, significant differences were determined among 10-12 age group soccer players' Illinois agility test values. The sources of differences were those 12 age group soccer players according to 10 and 11 age group showed better performances. Consequently, it can be said that agility property which consist suddenly acceleration, change direction and stop actions are affected by age positively in these age groups. In order to improve 
Sayg1n, Ö., Göral, K., Ceylan, H. İ., \& Karacabey, S. (2015). Investigation of agility performance on 10-12 years soccer players. International Journal of Human Sciences, 12(2), 1912-1917. doi:10.14687/ijhs.v12i2.3521

the agility characteristic in children, age factor can be considered in the preparation of training programs.

\section{References}

Alanazi, H.M.N., Aouadi, R. (2015). Reaction time as a predictor for change-of-direction speed in male soccer players. Saudi Journal of Sports Medicine, 15(3), 220-225.

Amiri-Khorasani, M., Sahebozamani, M., Tabrizi, K.G., Yusof, A.B. (2010). Acute effect of different stretching methods on Illinois agility test in soccer players. J Strength Cond Res, 24(10), 2698-2704.

Bidaurrazaga-Letona, I., Carvalho, H.M., Lekue, J.A., Badiola, A., Figueiredo, A.J., Gil, S.M. (2015). Applicability of an agility test in young players in the soccer field. Revista Brasileira de Medicina do Esporte, 21(2): 133-138.

Cetin, E. (2013). Is there a gender difference for agility in children age 7-12 years? International Journal of Academic Research, 5(4), 87-90.

Dellal, A., Wong, D.P. (2013). Repeated sprint and change-of-direction abilities in soccer players: Effects of age group. The Journal of Strength \& Conditioning Research, 27(9), 2504-2508.

Gunay, M., Yuce, A.I. (2008). Futbol antrenmanmnn bilimsel temelleri (Genişletilmiş 3. Baski) Ankara: Gazi kitapevi.

Hazir, T., Mahir, O.F., Acikada, C .(2010). Genç futbolcularda çeviklik ile vücut kompozisyonu ve anaerobik güç arasındaki ilişki. Hacettepe Journal of Sport Sciences, 21(4), 146-153.

Homoud, M.N.A. (2015). Relationships between illinois agility test and reaction time in male athletes. The Swedish Journal of Scientific Research, 2(3), 28-33.

Karacabey, K. (2013). Sporda performans ve çeviklik testleri. International Journal of Human Sciences, 10(1), 1693-1704.

Kizilet, A., Atilan, O., Erdemir, İ. (2010). 12-14 yaş grubu basketbol oyuncularının çabukluk ve sıçrama yetilerine farklı kuvvet antrenmanlarının etkisi. Journal of Physical Education and Sport Sciences, 12(2), 44-57.

Little, T., Williams, A.G. (2005). Specificity of acceleration, maximum speed, and agility in professional soccer players. Journal of Strength and Conditioning Research, 19(1), 76-78.

Pettersen, S.A., Mathisen, G.E. (2012). Effect of short burst activities on sprint and agility performance in 11- to 12- year-old boys. Journal of Strength and Conditioning Research, 26(4), $1033-1038$.

Rowland, T.W. (2005). Children's exercise physiology. Champaign, IL: Human Kinetics.

Sheppard, J.M., Young, W.B. (2006). Agility literature review: Classifications, training and testing. Journal of Sports Sciences, 24(9), 919-932.


Yayımevi.

Verschuren, O., Bloemen, M., Kruitwagen, C., Takken, T. (2010). Reference values for anaerobic performance and agility in ambulatory children and adolescents with cerebral palsy. Developmental Medicine \& Child Neurology, 52, 222-228.

Young, W., Farrow, D. (2006). A Review of agility: Practical applications for strength and conditioning. Strength and Conditioning Journal, 28, 24-29.

Zemkova, E., Hamar, D. (2014). Age-related changes in agility time in children and adolescents. International Journal of Science and Research, 3(11), 280-285.

Zorba, E., Saygin, O. (2009). Fizilksel aktivite ve uygunluk. Ankara: İnceler Ofset. 